\title{
Notes on pyrenomycetous fungi in the Mountain Lake area of southwestern Virginia
}

\section{Vasilyeva $\mathrm{LN}^{1}$ and Stephenson $\mathrm{SL}^{2}$}

${ }^{1}$ Institute of Biology and Soil Science, Far East Branch of the Russian Academy of Sciences, Vladivostok, 690022, Russia.E-mail:vasilyeva@biosoil.ru

${ }^{2}$ Department of Biological Sciences, University of Arkansas, Fayetteville, Arkansas 72701, USA

Vasilyeva LN, Stephenson SL 2014 - Notes on pyrenomycetous fungi in the Mountain Lake area of southwestern Virginia. Mycosphere 5(1), 218-227, Doi 10.5943/mycosphere/5/1/11

\begin{abstract}
Results of a survey for pyrenomycetous fungi carried out in the upland forests of the Mountain Lake area of southwestern Virginia are presented. The list of species found includes 31 different entities. Four species-Diatrype aceris-rubri, Hypoxylon virginianum, Lopadostoma cryptosphaeroides, and Xylomelasma moderata-are described as new to science.
\end{abstract}

Key words - ascomycetous fungi - Diatrype - Hypoxylon - Lopadostoma - upland forests taxonomy - Xylomelasma

\section{Introduction}

A short survey of pyrenomycetous fungi carried out in the upland forests of the Mountain Lake area of southwestern Virginia from July 26 to August 5 in 2013 yielded a relatively small number of species. Nonetheless, the species that were collected do demonstrate some of the ecological and biogeographical regularities known for the distribution patterns of this group of fungi in eastern North America, and there were several taxonomic novelties.

Because of high degree of association of many species, especially diatrypaceous and xylariaceous ones, with certain genera of host plants, one of the first tasks involved in a survey of a limited area is to compare the expected and observed species diversity on the particular trees dominating the vegetation and then to come to some conclusions as to what accounts for the apparent difference.

\section{The General Study Area}

The Mountain Lake area of southwestern Virginia (latitude $37^{\circ} 22^{\prime} \mathrm{N}$, longitude $80^{\circ} 37^{\prime} \mathrm{W}$ ) is located on Salt Pond Mountain in Giles County, which is within the Ridge and Valley physiographic province of the southern Appalachian Mountains (Fenneman 1938, Stephenson 1988). Braun (1950) included the Mountain Lake area within the Ridge and Valley Section of the Oak-Chestnut Forest Region. The major species of trees present are various species of oak, of which chestnut oak (Quercus prinus L.) and northern red oak (Q. rubra L.) are the most important. American chestnut (Castanea dentata [Marsh.] Borkh.), formerly a dominant or codominant species in these forest communities, was almost completely eliminated by the chestnut blight, which was caused by the the diaporthaceous fungus Cryphonectria parasitica (Murrill) M.E. Barr during the first half of the twentieth century (Stephenson 1986). 


\section{Materials \& Methods}

Microscopic analyses were carried out using standard techniques. Observations and measurements of asci and ascospores were made using Zeiss Primo Star and Leica DM 4500B microscopes. The photographs of stromata were taken using a Nikon D40x digital camera.

\section{Taxonomic observations}

Diatrype aceris-rubri Lar.N. Vasilyeva \& S.L. Stephenson, sp. nov. MycoBank 807043

Fig. 1A-B.

Etymology - aceris-rubrae refers to the frequent association with Acer rubrum.

Stromata mostly small, rounded or irregular, $1.5-3 \mathrm{~mm}$ diam., or confluent and becoming larger and wider effused, erumpent from the bark, $0.7-1 \mathrm{~mm}$ thick, oulined by a black stromatic zone in the substrate, dark brown to blackened, ostioles stellate. Perithecia in one or two layers, 150-200 $\mu \mathrm{m}$ diam., clearly outlined by a black line and with white tissue above. Asi clavate, 35-40 $\times 5-7 \mu \mathrm{m}$ in spore-bearing part, with stalks $25-30 \mu \mathrm{m}$ and a tiny, J-positive apical ring. Ascospores allantoid, brownish, 7-9 × 1.8-2.2 $\mu \mathrm{m}$.

Material examined - USA, Virginia, Giles County, Salt Pond Mountain, on the bark of Acer rubrum L., 29 July 2013, L. Vasilyeva, VLA P-2798 (holotype); Michigan, Cheboygan County, Douglas Lake, on Acer rubrum, 9 Aug 2010, L. Vasilyeva, VLA P-2799.

Notes - The effused stromata of Diatrype aceris-rubrae are similar to those of D. spilomea Syd., but the latter species has smaller ascospores $(4.5-7 \times 1-1.2 \mu \mathrm{m})$ (Rappaz 1987). Diatrype rappazii (Chleb.) Lar.N. Vassilyeva, sometimes reported from Acer spp., has larger ascospores (9$12 \mu \mathrm{m}$ long in average) (Chlebicki \& Krzyzanowska 1995) and strongly undulate stromatal surface. Diatrype polycocca Fuckel, known from Europe on Acer opalus Mill., has even larger ascospores (up to $15 \mu \mathrm{m}$ long) (Rappaz 1987).

Hypoxylon virginianum Lar.N. Vassiljeva \& S.L. Stephenson, sp. nov.

Figs. 2A, 3A-D MycoBank 807044

Etymology - virginianum refers to the holotype from Virginia.

Stromata effused-pulvinate, sometimes pulvinate or even hemisphaerical, surface reddish brown, with inconspicous or conspicuous perithecial mounds, often shining black at the tops, sometimes surrounded by young brick coloured tissue at the margins, red granules immediately beneath surface and between perithecia, with $\mathrm{KOH}$-extractable pigments orange. Perithecia spherical, 250-300 $\mu \mathrm{m}$ diam., ostiloles umbilicate. Asci 60-70 $\times 5-6 \mu \mathrm{m}$ in spore-bearing part, with stalks up to $60 \mu \mathrm{m}$ and apical ring bluing in Melzer's iodine reagent, discoid, 2.2-2.5 $\times 1 \mu \mathrm{m}$. Ascospores brown to dark brown, unicellular, ellipsoid-inaequilateral, 9-11(-12.5) $\times 2-2.5 \mu \mathrm{m}$, with straight germ slit spore-length on the convex side; perispore dehiscent in $10 \% \mathrm{KOH}$, smooth.

Material examined - USA, Virginia, Giles County, Salt Pond Mountain, on the bark of Acer pennsylvanicum L., 1 Aug 2013, L. Vasilyeva, VLA P-2772 (holotype); John's Creek Trail, on A. pennsylvanicum, 28 Jul 2013, L. Vasilyeva; Pipeline Trail, on A. pennsylvanicum, 28 Jul 2013, L. Vasilyeva; Spring Road, on A. pennsylvanicum, 29 Jul 2013, L. Vasilyeva; Moonshine Dell Trail, on A. pennsylvanicum, 31 Jul 2013, L. Vasilyeva.

Notes - This species is the most common pyrenomycetous fungus occurring the bark of Acer pennsylvanicum in the vicinity of Mountain Lake and does not occur on other trees. It fits the description of Hypoxylon rubiginosum (Pers.) Fr. in many features (Ju \& Rogers 1996) but differs in the presence of red granules immediately beneath stromatal surface and between perithecia, as well as in stromatal shape and colour (Fig. 2). Hypoxylon rubiginosum is supposed to be widely distributed in northern hemisphere, but it surely represents a species complex that includes entities restricted to certain areas and substrates. 


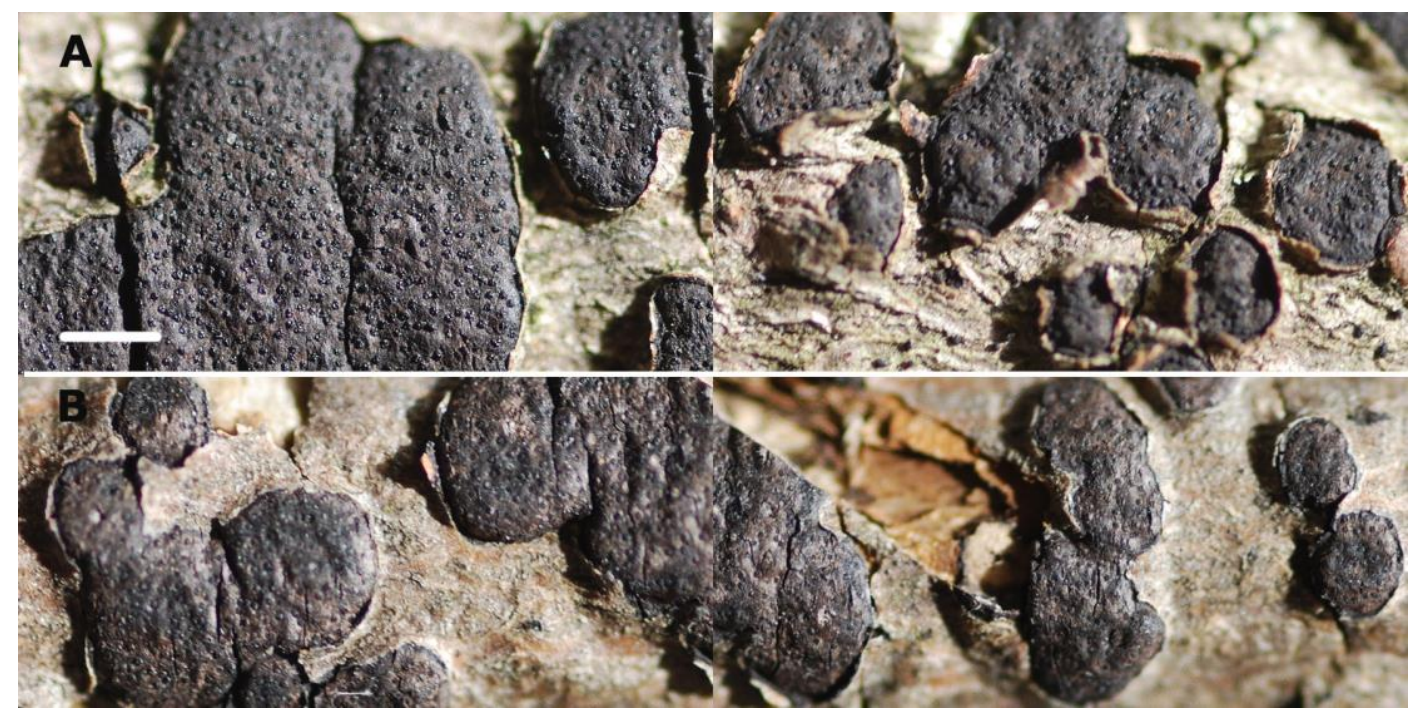

Fig. 1A-B - Stromata of Diatrype aceris-rubrae. A, From Virginia (holotype). B, From Michigan. - Bar AB: $1 \mathrm{~mm}$.

Among synonymous names listed under $H$. rubiginosum ( Ju \& Rogers 1996), only $H$. florideum Berk. \& M.A. Curtis is relevant to the species described from eastern North America. The lectotype of the latter is kept in the Kew Herbarium at the Royal Botanic Gardens and reported from wood of unidentified tree (Ju \& Rogers 1996). However, H. florideum was described from Acer rubrum (Berkeley 1875), and this makes the comparison of $H$. virginianum and $H$. florideum to be most necessary. The type specimen of H. florideum from Ravenel's herbarium has dark vinaceous stromata spreading on wood which are more similar to H. fendleri Berk. Hypoxylon florideum might be resurrected from ' $H$. rubiginosum' complex, especially taking into account the "Florida-Texas" distribution pattern (Wu \& Mueller 1997). The latter refers to the restriction of some species to the southeastern states of the United States of America, but $H$. florideum differs from $H$. virginianum in stromatal features and seems to have more southern distribution.

Lopadostoma cryptosphaeroides Lar.N. Vassiljeva \& S.L. Stephenson, sp. nov.

Figs. 4A-C MycoBank 807045

Etymology - cryptosphaeroides refers to the appearance of stromata which reminds of those of Cryptosphaeria members.

Stromata immersed in bark, aggregated under swollen and often blackened epidermis, erumpent with tiny, black, rounded or slightly elliptical ectostomatic disc $0.5-1 \times 0.3-0.5 \mathrm{~mm}$. Perithecia immersed at the bases of stromata, 400-500 $\mu \mathrm{m}$ diam. Asci narrow cylindric, $65-75 \times$ 3.5-4 $\mu \mathrm{m}$, with stalks up to $50 \mu \mathrm{m}$ long and apical ring bluing in Melzer's iodine reagent, discoid, 2.2-2.5 × $1 \mu \mathrm{m}$. Ascospores fusiform, with rounded ends, brown, 9-12.5(-15) × 3-3.5 $\mu \mathrm{m}$.

Material examined - USA, Virginia, Giles County, Salt Pont Mountain, on the bark of Quercus sp., 3 Aug 2013, L. Vasilyeva, VLA P-2796 (holotype); Maryland, Catoctin Mountain Park, on Quercus sp., 27 Apr 1997, L. Vasilyeva, VLA P-2797.

Notes - The genus Lopadostoma has not received much attention from taxonomists, and there are no good explanations as to its differences from Anthostoma. The members of Anthostoma seem to correspond to the section Euanthostoma within this genus described as having "stromate late effuso, eutypeo" (Saccardo 1882). The second section within Anthostoma, namely Fuckelia, was characterized as having "stromate valseo, v. erumpenti-verruciformi" (1.c.). The difference is not a bad one and serves as the basis for making some generic discriminations (for example, Eutypa and Eutypella). Earlier, Nitschke (1867) divided the genus Anthostoma into the sections Anthostoma ("stromata diatrypeum, ligno v. rarius cortici crassiori emmersum") and Lopadostoma ("stroma valseum"), the latter with a single species A. turgidum (Pers.) Nitschke. 

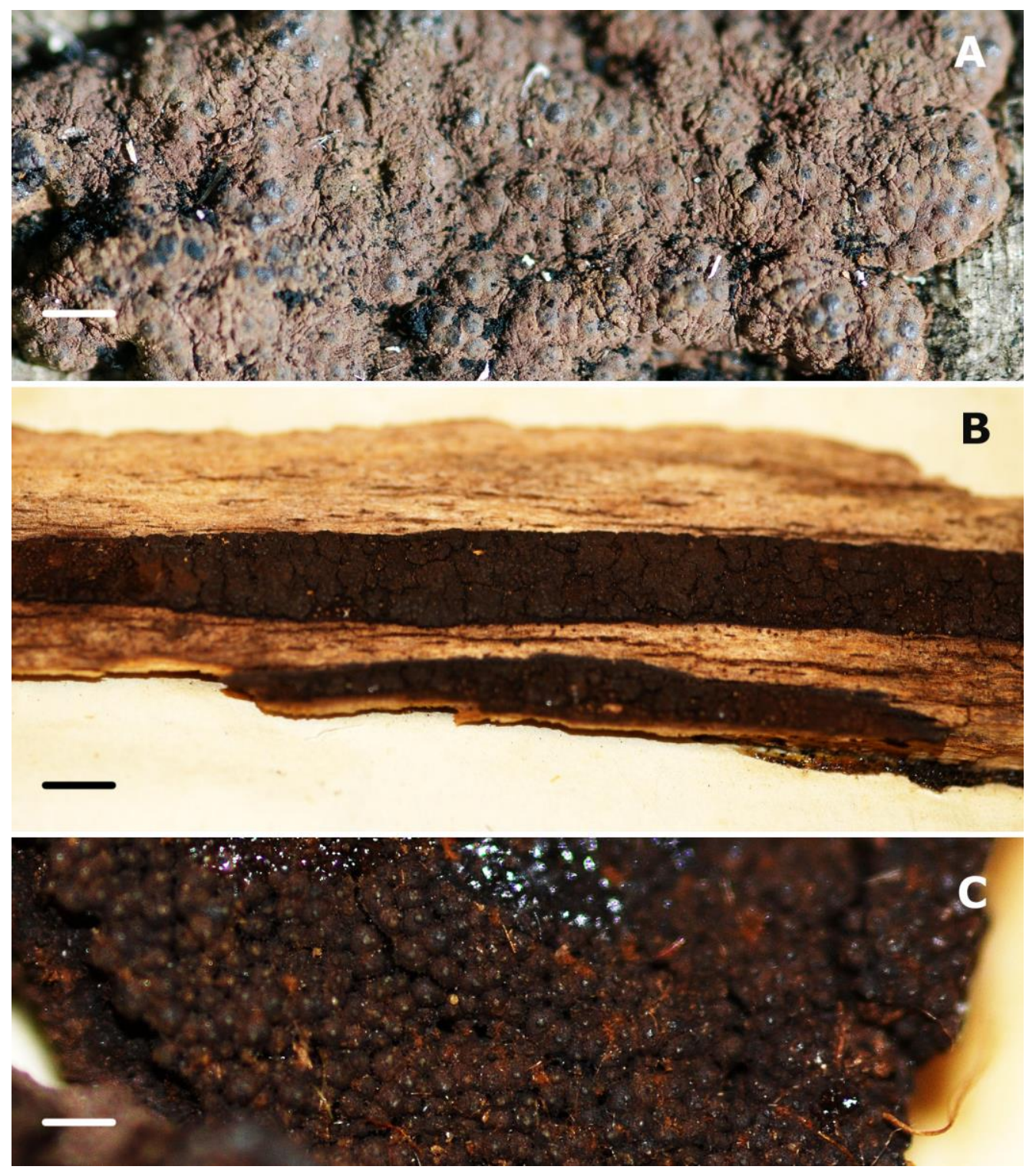

Fig. 2A-C - Stromata. A, Hypoxylon virginianum. B-C, H. rubigibosum (stromatal outline and surface from the type, K). - Bars A, C: $1.2 \mathrm{~mm}$; B: $10 \mathrm{~mm}$.

Traverso (1906) made a genus of the section Lopadostoma and included four species- $L$. gastrinum (Fr.) Traverso, L. massarae (De Not.) Traverso, L. taeniosporum (Sacc.) Traverso, and $L$. turgidum (Pers.) Traverso. Currently, two of these (the first and last) are treated as Anthostoma, whereas the other two as Lopadostoma (www.speciesfungforum.org). This treatment is not supported by any taxonomic considerations, and one of the few papers dealing with Anthostoma and Lopadostoma (Martin 1969) has acknowledged L. gastrinum and L. turgidum.

Rappaz (1995) created a new genus Barrmaelia, which includes some species traditionally placed within Anthostoma, and prepared a key for "xylariaceous genera" where Lopadostoma is distinguished from Barrmaelia (along with Leptosmassaria and some species on Anthostomella) in having "ascospores 1 celled, smaller than $12 \mu \mathrm{m}$; asci with an apical ring I+, 1-1.5 $\mu \mathrm{m}$ high", whereas the compared entities have "ascospores and apical ring larger", and Barrmaelia in particular "has ascospores 1 celled' apical ring I-". This is really an unwarranted discrimination of genera, since it is carried out on the basis of characters that are usually of importance only for species delimitation within all genera of the Xylariaceae. Thus far, we are forced to look for descriptions of all species assigned to both genera when we find something suggesting either Anthostoma or Lopadostoma, since the concepts remain uncertain. 


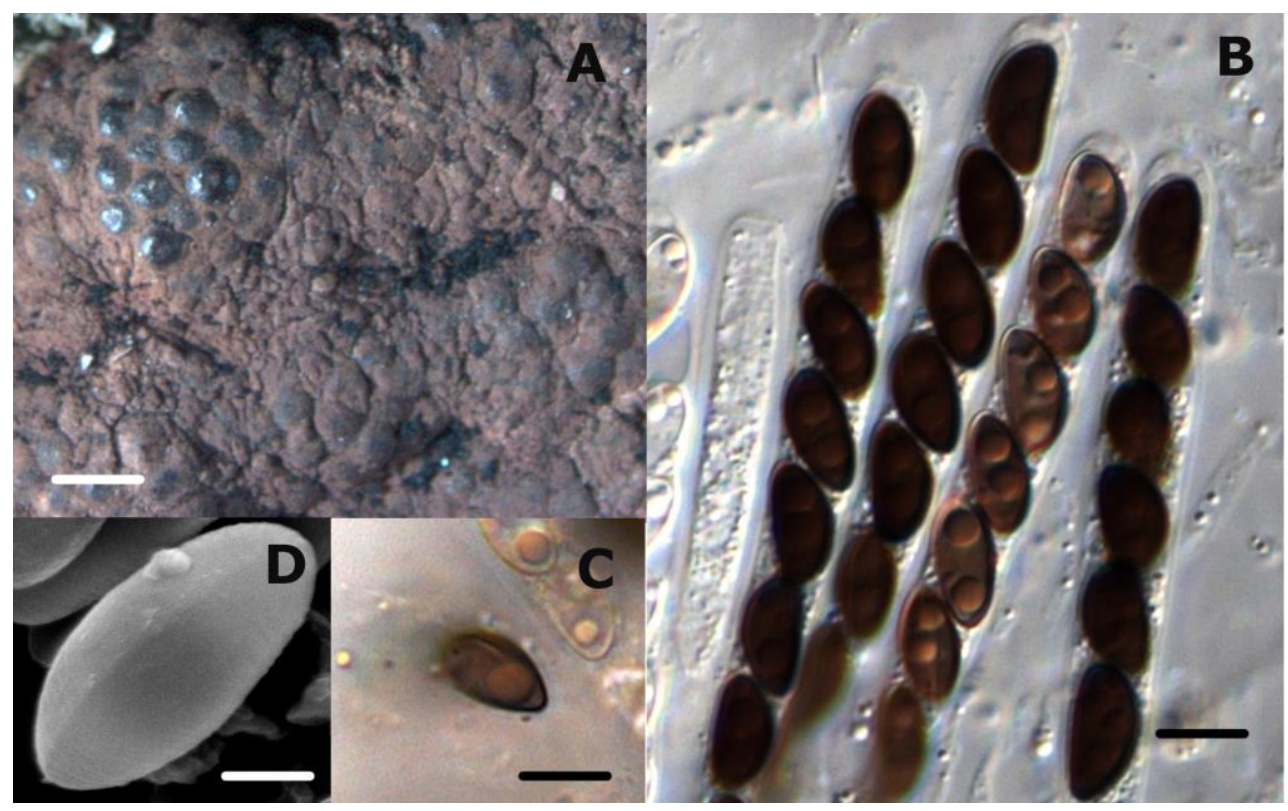

Fig. 3A-D - Hypoxylon virginianum. A, Stromatal surface. B, Asci and ascospores. C Spore with a germ slit visible on a convex side. D SEM image of a spore. - Bars A: $0.75 \mathrm{~mm}$; B: $6 \mu \mathrm{m}$; C: $7.5 \mu \mathrm{m}$; D: $2.5 \mu \mathrm{m}$.

The North American representatives of the genera in question are six species of Anthostoma and four species of Lopadostoma (Farr et al. 1989). Of these, Anthostoma quercina (Petr.) Arx \& E. Müll. based on Leptomassaria quercina Petr. and described from Maryland (Petrak 1952) is Amphirosellinia quercina (Petr.) Y.M. Ju et al. (Ju et al. 2004). Other species indicated in association with Quercus spp. (Farr et al. 1989) are Lopadostoma gastrinum and L. sphinctrinum (Fr.) P.M.D. Martin, the latter with a synonymous name Anthostoma dryphilum (Curr.) Sacc.

The synonymization of A. dryophilum and 'A. sphinctrinum (Fr.) Sacc.' was made by Martin (1969) without any explanation, whereas Saccardo (1882) did not make a combination 'Anthostoma sphinctrinum'; instead, he indicated Sphaeria sphinctrina Fr. as a synonym of Anthostoma turgidum. Both S. sphinctrina and A. turgidum seem to be restricted to Fagus, and it is possible that the specimen of Lopadostoma sp. on Fagus from Austria, differing from L. turgidum in narrow ascospores (Vasilyeva \& Scheuer 1996), is exactly L. sphinctrina, and this corresponds to the range of ascospore size $(9-9.5 \times 3.5-4 \mu \mathrm{m})$ indicated by Martin (1969) for the latter species. Anthostoma dryophilum is hardly a synomym of L. sphinctrina; it was described with an ascospore length of 10.16-12.7 $\mu \mathrm{m}$ (Currey 1858) and seems to be restricted to Quercus.

Ellis \& Everhart (1892) have reported A. dryophilum on Quercus spp. from New Jersey, Texas and Iowa, but the American specimens might not be conspecific with European ones. The mediated evidence for their difference is the reference to Ellis's exsiccate 'North American Fungi No. 87' as exemplified 'A. dryophilum' from North America (Ellis \& Everhart 1892). However this exsiccate specimen represents only A. dryophilum var. minor Cooke. The latter was described as having "stromata more effused and less prominent, covered except the small, tuberculiform disk, by the blackened epidermis". The appearance of such stromata could be observed here in the photo (Fig. 4C) illustrating a specimen on Quercus found in the Big Thicket National Preserve (Texas). The stromata of Lopadostoma cryptosphaeroides are similar in being somewhat effused under the blackened epidermis (Fig. 4A-B), but they are more robust and have larger ectostromatic discs. (The specimen from Texas also differs in smaller ascospores that are only 7-9 $\mu \mathrm{m}$ long.) However, although L. cryptosphaeroides might be considered as the 'major' variation of A. dryophilum var. minor, we cannot identify our specimens as true A. dryophilum since all available description of the latter do not mention the stromatal characters which are typical for L. cryptosphaeroides. When Currey (1858) described A. dryophilum, he indicated its resemblances to Sphaeria verruciformis Ehrh [i.e., Diatrypella verruciformis (Ehrh.) Nitschke] in "its external form", and this is completely different from the appearance of L. cryptosphaeroides. 


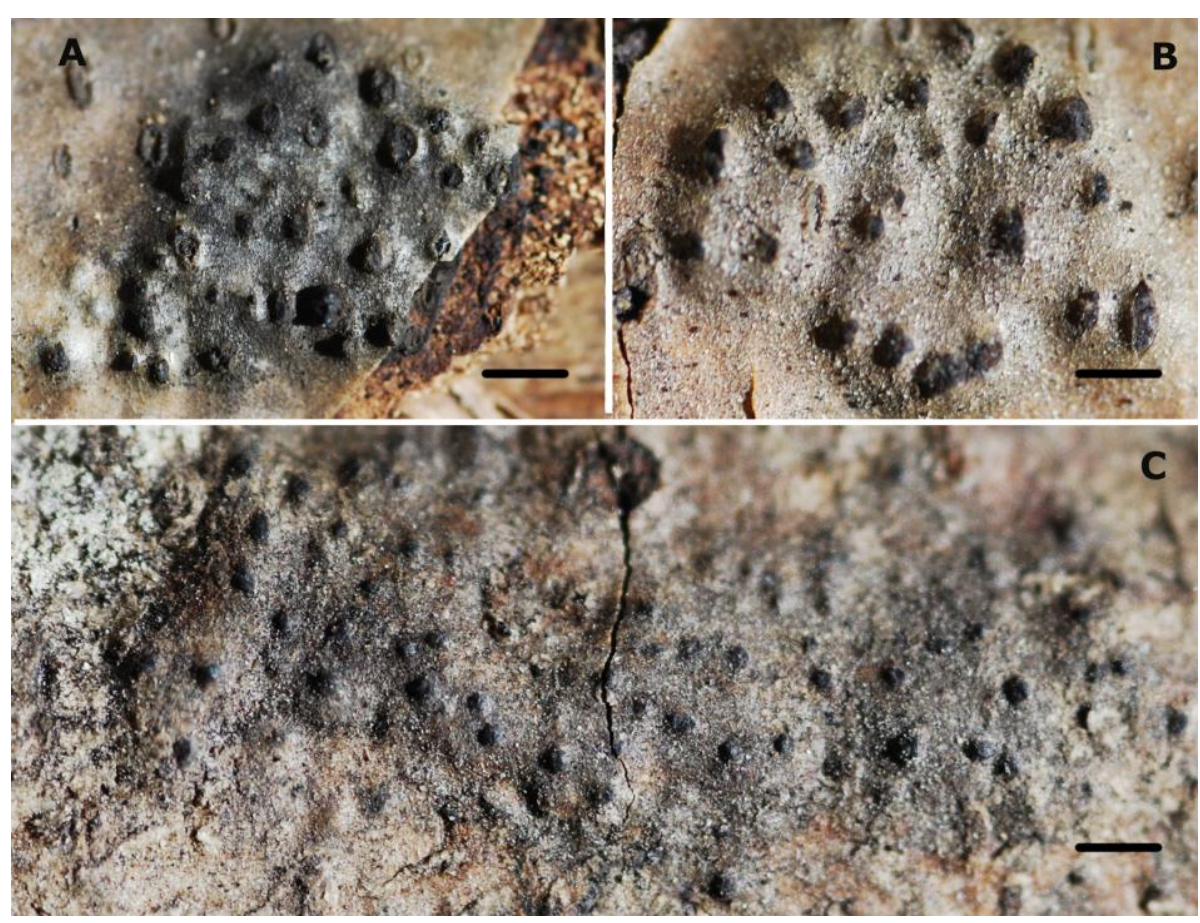

Fig. 4A-C - Stromata. A-B, Lopadostroma cryptosphaeroides from Virginia (holotype) and Maryland. C, Lopadostoma sp. from Big Thicket National Preserve (Texas) with the appearance of L. dryophylum var. minor (Ellis, North American Fungi N 87) but smaller ascospores. - Bars A: $2 \mathrm{~mm}$; B: $1.2 \mathrm{~mm}$; C: $1 \mathrm{~mm}$.

Xylomelasma moderata Lar.N. Vassiljeva \& S.L. Stephenson, sp. nov.

Figs. 5A-B

MycoBank 807047

Etymology - moderata refers to the occurrence in temperate forests.

Perithecia solitary to gregarious, globose to subglobose, 400-500 $\mu \mathrm{m}$ diam., semi-immersed or immersed in the wood, glabrous or roughened, dark brown to black, surrounded by sparse mycelium; hyphae growing out of the bottom part of the outer perithecial wall; necks elongate, cylindrical, central or lateral, glabrous, 140-150 $\mu \mathrm{m}$ long, sometimes slightly swollen at the tips. Paraphyses not seen. Asci unitunicate, 8-spored, cylindrical, 60-80 × 7.5-9 $\mu \mathrm{m}$, short-stipitate, floating freely within the centrum at maturity, with a distinct, refractive, nonamyloid apical annulus ca. $2.5 \times 1 \mu \mathrm{m}$ high. Ascospores unicellular, ellipsoidal to oblong, 12-14 × 4.5-5.5(-6) $\mu \mathrm{m}$, pale brownish, obliquely 1 -seriate in the ascus.

Material examined - USA, Virginia, Giles County, Salt Pond Mountain, on rotten wood, 5 Aug 2013, L. Vasilyeva, VLA P-2768 (holotype).

Notes - The genus Xylomelasma was established recently (Réblová 2006) with two species, X. sordida Réblová and X. novaezelandiae Réblová, both of which have smaller ascospores in comparison with $X$. moderata. Rather similar is also Lentomitella tomentosa Réblová \& J. Fournier, which has somewhat larger ascospores than $X$. moderata. The latter species is placed apart from the members of Xylomelasma because of its hyaline ascospores. Nevertheless, L. tomentosa does not seem properly arranged within the genus Lentomitella because of aseptate spores in contrast to other species of that genus.

\section{Discussion}

As already noted, various species of oaks are the dominant trees in most of the forests present in the Mountain Lake area, and the usual complex of pyrenomycetous fungi associated with the substrates provided by oaks in the temperate forests of eastern North America were recorded. Among these were Annulohypoxylon annulatum (Schwein.) Y.M. Ju et al., Biscogniauxia atropunctata (Schwein.) Pouzar, Camillea punctulata (Berk. \& Ravenel) Læssøe et al., Diatrype atlantica Lar.N. Vassiljeva, Eutypa limiformis (Schwein.) Berk., as well as Lopadostoma 


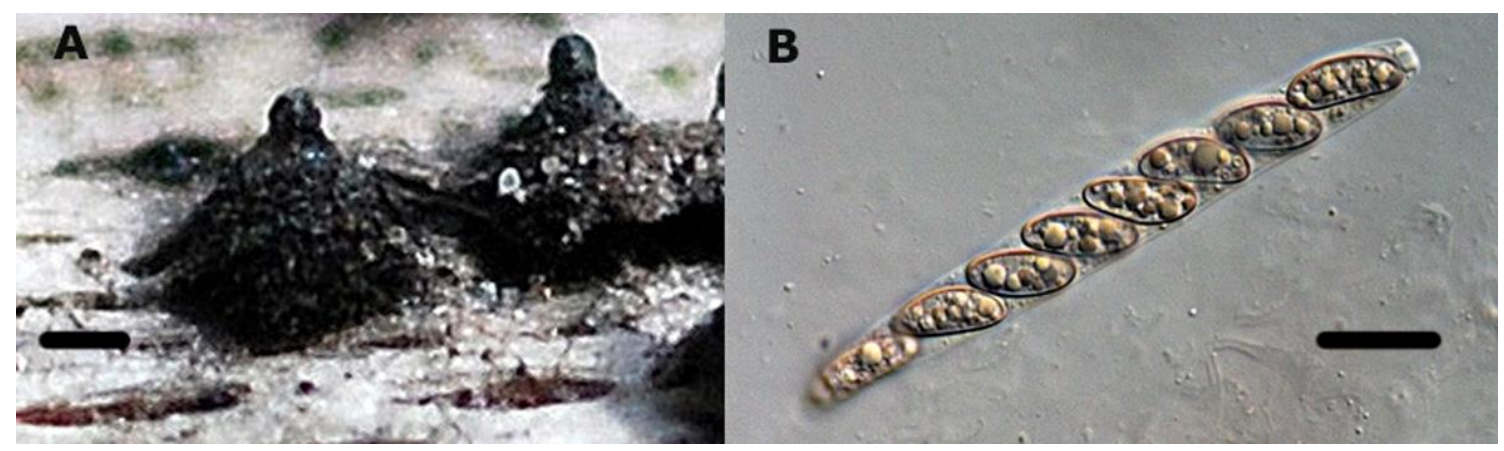

Fig. 5A-B - Xylomelasma moderata. A, Ascomata. B, Ascus with ascospores. Bars A: $150 \mu \mathrm{m}$; B: $13 \mu \mathrm{m}$.

cryptosphaeroides sp. nov. Almost all of these species are restricted to eastern North America except for Annulohypoxylon annulatum, which also is found in northeastern Asia on Quercus spp. and thus belongs to the special group of pyrenomycetous fungi that demonstrate an 'Asa Gray disjuction' in their distribution (Vasilyeva \& Stephenson 2010). The same can be said for Graphostroma platystoma (Schwein.) Piroz. and Nitschkia modesta Lar.N. Vassiljeva et al., both observed in the Mountain Lake area. The latter species was described quite recently from northeastern Asia (Vasilyeva et al. 2010), and finding it in southwestern Virginia is the first record in North America.

Extremely poor was the collecting of species usually associated with Fagus grandifolia Ehrh. Only common Diatrype decorticata (Pers.) Rappaz and Hypoxylon fragiforme (Scop.) Kickx were encounteted, and both were in bad condition, either very old or immature, respectively. The high elevation of the Mountain Lake area (much of it at or above $1200 \mathrm{~m}$ ) might be responsible for the shift of development of some species toward a later period of the year or for a reduction of the normal species complex. Perhaps the short period of survey was also influential because of a very peculiar situation in connection with substrates in many forests of eastern North America. This means that despite the abundance of promising (in respect to be possible substrates) trees lying on the ground, these logs were in such a weathered condition that they could not serve for the development of pyrenomycetous fungi at all. This also means that one should expect to spend much more time to find a log that can provide a niche for the expected species.

American chestnut was clearly the predomiant species in some forest communities in the Mountain Lake area prior to the arrival of the blight. For example, Braun (1950), who carried out a survey of forest composition on the slope of Bald Knob on Salt Pond Mountainin 1932, indicated that chestnut made up as much as 85 percent of the canopy. However, this tree now occurs only as stump sprouts that are dying from the chestnut blight fungus, and the vast majority of these stump sprouts do not exceed $2.5 \mathrm{~cm}$ DBH (Stephenson et al. 1991). The thin dead sprouts do not provide a substrate of sufficient size to be suitable for the development of the few saprotrophic pyrenomycetes known to be associated with Castanea.

\section{Preliminary list of pyrenomycetous species in the Mountain Lake area}

\section{Coronophorales}

Nitschkia modesta Lar.N. Vassilyeva, Chernyshev \& S.L. Stephenson - on the bark and wood of unidentified trees, near the road from the Biological Station to Mountain Lake, 5.08.13.

Tympanosis confertula (Schwein.) Lar.N. Vassiljeva - on wood, Rhododendron Trail, 28.07.13.

\section{Endoxylales}

Xylomelasma moderata Lar.N. Vassiljeva \& S.L. Stephenson- on decayed wood, near the road from the Biological Station to Mountain Lake, 5.08.13. 
Diaporthales

Cryphonectria parasitica (Murrill) M.E. Barr - on a dead but still standing small tree of Castanea dentata, Hedwig Trail, 1.08.13.

Diatrypales

Diatrype atlantica Lar.N. Vassiljeva - on Quercus spp., Pipeline Trail, 29.07.13; Spring Trail, 2.08.13; Moonshine Dell Trail, 3.08.13; Sartain Branch Trail, 3.08.13.

Diatrype decorticata (Pers.) Rappaz - on Fagus grandifolia, in the vicinity of the Biological Station, 4.08.13.

Diatrype subaffixa (Schwein.) Cooke - on dead branches of Prunus serotina, Hedwig Trail, 30.07.13; Sartain Branch Trail, 3.08.13.

Diatrype aceris-rubri Lar.N. Vasilyeva \& S.L. Stephenson - on dead branches of Acer rubrum, vicinity of the Mountain Lake Lodge, 29.07.13.

2.08.13.

Diatrype undulata (Pers.) Fr. - on Betula spp., Rhododendron Trail, 26.07.13; Spring Trail,

Eutypa lata (Pers.) Tul. \& C. Tul. - on decayed wood of an unidentified tree, Rhododendron Trail, 28.07.13.

Eutypa leioplaca (Fr.) Cooke - on wood of Acer pennsylvanicum, Spring Road, 29.07.13; on Acer rubrum, near the road from the Biological Station to Mountain Lake, 5.08.13. 13

Eutypa limiformis (Schwein.) Berk. - on Quercus spp., Maple Trail, 4.08.13; Bear Cliffs Trail, 30.07.13.

Graphostroma platystoma (Schwein.) Piroz. - on dead branches of Acer pennsylvanicum, Bear Cliffs Trail, 29.07.13; on Prunus serotina Ehrh., Sartain Branch Trail, 3.08.13; on Acer rubrum, in the vicinity of the Biological Station, 4.08.13.

Lopadostoma cryptosphaeroides Lar.N. Vassiljeva \& S.L. Stephenson - on bark of Quercus sp., Moonshine Dell Trail, 3.08.13.

Hypocreales

Cordyceps militaris (L.) Fr. - on insect pupae, White Pine Trail, 28.07.13; Pipeline Trail, 29.07.13; Spruce Bog Trail, 1.08.13.

Dialonectria episphaeria (Tode) Cooke - on old stromata of Diatrype atlantica, in the vicinity of the Biological Station, 26.07.13.

Hypocrea patella Cooke \& Peck - on bark of Quercus sp., White Pine Trail, 28.07.2013.

Protocrea pallida (Ellis \& Everh.) Jaklitsch, K. Põldmaa \& Samuels - on an aphyllophoraceous fungus, Middle Jungle Trail, 5.08.13.

Xylariales

Annulohypoxylon annulatum (Schwein.) Y.M. Ju, J.D. Rogers \& H.M. Hsieh - on Quercus spp., John's Creek Trail, 28.07.13; chestnut plot near the Moonshine Dell Trail, 4.08.13.

Biscogniauxia atropunctata (Schwein.) Pouzar- on Quercus spp., Maple Trail, 28.07.13; Spring Road, 29.07.13; in the vicinity of the Biological Station, 3.08.13 \& 4.08.13.

Camillea punctulata (Berk. \& Ravenel) Læssøe, J.D. Rogers \& Whalley - on Quercus sp., in the vicinity of the Biological Station, 5.08.13.

Daldinia childiae J.D. Rogers \& Y.M. Ju - on a dead but still standing trunk, Spruce Bog Trail, 1.08.2013.

Hypoxylon fragiforme (Scop.) Kickx - on Fagus grandifolia, in the vicinity of the Biological Station, 4.08.13.

Hypoxylon rutilum Tul. \& C. Tul. - on Fagus grandifolia, in the vicinity of the Biological Station, 26.07.13.

Rather tentatively, we assigned one of the specimens found on Fagus grandifolia to Hypoxylon rutilum. This species is most found in Europe, and only one collection is known from 
Asia (Ju \& Rogers 1996). There were no reliable records from North America, but this species could be expected on Fagus here. Our specimen is not very similar to images of European specimens assigned to this species (http://pyrenomycetes.free.fr), but its features fit the description well and the general habitus of stromata is the same as illustrated by Miller (1961, Fig. 69).

Hypoxylon virginianum Lar.N. Vassiljeva \& S.L. Stephenson - on bark of Acer pennsylvanicum, John's Creek Trail, 28.07.13; Pipeline Trail, 28.07.13; Spring Road, 29.07.13; Moonshine Dell Trail, 31.07.13.

Nemania serpens (Pers.) Gray - on decayed wood, Spring Road, 30.07.13; Spruce Bog Trail, 1.08.13.

Rosellinia subiculata (Schwein.) Sacc. - on decayed wood, Moonshine Dell Trail, 2.08.13.

Ustulina deusta (Hoffm.) Lind- on an old stump, in the vicinity of the Biological Station, 1.08.13.

Xylaria longiana Rehm - on bark of Quercus sp., in the vicinity of the Biological Station, 5.08.13.

The specimen of Xylaria longiana was assigned to this species mostly because of the consideration that it "grows on the wood of oaks in eastern North America" (http://www.mushroomexpert.com). Its stromata are similar to those illustrated by Michael Kuo (the above site) and the size of ascospore is the same $(9-11 \times 4-5 \mu \mathrm{m})$, but the stromata in our specimen are only up to $1.5 \mathrm{~cm}$, whereas the description gives them as $2-8 \mathrm{~cm}$ tall. Xylaira longiana was described originally from Texas (Rehm 1906) with stromata 3-3.5 cm long and slightly smaller ascospores $(8-9 \times 4 \mu \mathrm{m})$. However, afterwards the concept of $X$. longiana included an ascospore range of $9-11 \times 4-5 \mu \mathrm{m}$ (Rogers 1986). As for the length of the stromata, it seems to be very variable in the same species (cf. Fournier et al. 2011, Fig. 1a).

Pleosporales

Apiosporina morbosa (Schwein.) Arx - on a living branch of Prunus serotina, in the vicinity of the Biological Station, 4.08.13.

Hysteriales

Glonium stellatum Muhl. - on a dead log on the forest floor, Sartain Branch Trail, 3.08.13.

\section{Acknowledgements}

We express our thanks to the personnel of the Mountain Lake Biological Station, especially Jaime Jones, for assisting with various aspects of the visit by the first author.

\section{References}

Berkeley MJ. 1875 - Notices of North American Fungi. Grevillea 3, 45-52.

Braun EL. 1950 - Deciduous Forests of Eastern North America. The Blakiston Company, Philadelphia.

Chlebicki AJ, Krzyzanowska J. 1995 - Notes on Pyrenomycetes and Coelomycetes from Poland 3. Diatrype subaffixa, a new species for Europe. Sydowia 47, 10-30.

Currey F. 1858 - Synopsis of the fructification of the compound Sphaeriae of the Hookerian Herbarium. Transactions of the Linnean Society of London 22, 257-287.

Ellis JB, Everhart BM. 1892 - The North American Pyrenomycetes. Newfield.

Farr DF, Bills GF, Chamuris GP, Rossman AY. 1989 - Fungi on Plants and Plant Products in the United States. APS Press, St. Paul.

Fenneman NM. 1938 - Physiography of Eastern United States. McGraw-Hill Book Company, New York.

Fournier J, Flessa F, Peršoh D, Stadler M. 2011 - Three new Xylaria species from southwestern Europe. Mycological Progress 10, 33-52.

Ju YM, Rogers JD. 1996 - A revision of the genus Hypoxylon. Mycologia Memoir 20, 1-365. 
Ju YM, Rogers JD, Hsieh HM. Vasilyeva L. 2004 - Amphirosellinia gen. nov. and a new species of Entoleuca. Mycologia 96, 1393-1402.

Martin P. 1969 - Studies in the Xylariaceae: VII. Anthostomella and Lopadostoma. South African Journal of Botany 35, 393-410.

Miller JH. 1961 - A Monograph of the World Species of Hypoxylon. University of Georgia Press, Athens.

Nitschke T. 1867 - Pyrenomycetes Germanici. E. Trewendt, Breslau.

Petrak F. 1952 - Fungi beltsvillenses. Sydowia 6, 352-360

Rappaz F. 1987 - Taxonomie et nomenclature des Diatrypecées à asques octospores (1). Mycologia Helvetica 2, 285-648.

Rappaz F. 1995 - Anthostomella and related xylariaceous fungi on hard wood from Europe and North America. Mycologia Helvetica 7, 99-168.

Réblová M. 2006 - Molecular systematics of Ceratostomella sensu lato and morphologically similar fungi. Mycologia 98, 68-93.

Rehm H. 1906 - Ascomycetes Americae borealis. Annales Mycologici 2, 175-178.

Rogers JD. 1986 - Provisional keys to Xylaria species in continental United States. Mycotaxon 26, 85-97.

Saccardo P. 1882 - Sylloge Fungorum. Vol. 1. Patavii.

Stephenson SL. 1986 - Changes in a former chestnut-dominated forest after a half century of succession. American Midland Naturalist 116, 173-179.

Stephenson SL. 1988. Distribution and ecology of myxomycetes in temperate forests. I. Patterns of occurrence in the upland forests of southwestern Virginia. Canadian Journal of Botany 66, 2187-2207.

Stephenson SL, Adams HS, Lipford ML. 1991 - The present distribution of chestnut in the upland forests of the mid-Appalachians. Bulletin of the Torrey Botanical Club 118, 24-32.

Traverso JB. 1906 - Flora Italica Cryptogama. Pars I: Fungi. Pyrenomycetae 2, 1-352.

Vasilyeva LN, Scheuer C. 1996 - Neuere Aufsammlungen stromatischer Pyrenomyceten aus Österreich, insbesondere der Steiermark. Mitteilungen des Naturwissenschaftlichen Vereines für Steiermark 126, 61-82.

Vasilyeva LN, Stephenson SL. 2010 - Biogeographic patterns in pyrenomycetous fungi and their taxonomy. 1. The Grayan disjunction. Mycotaxon 114, 281-303.

Vasilyeva LN, Chernyshev SL, Stephenson SL. 2010 - Pyrenomycetes of the Russian Far East 4: family Nitschkiaceae (Coronophorales, Ascomycota). Mycologia 102, 233-247.

Wu QX, Mueller GM. 1997 - Biogeographic relationships between the macrofungi of temperate eastern Asia and eastern North America. Canadian Journal of Botany 75, 2108-2116. 